\title{
The American Jury at Twenty-Five Years
}

\section{Valerie P. Hans and Neil Vidmar}

Harry Kalven, Jr., and Hans Zeisel, The American Jury. Boston: Little, Brown, 1966. pp. 559.

The year 1991 marks the twenty-fifth anniversary of the publication of Harry Kalven, Jr. and Hans Zeisel's classic work, The American Jury. Arguably one of the most important books in the field of law and social science, this research monograph began the modern field of jury studies and deeply influenced contemporary understanding of the jury as an institution.

In this essay we assess the book from the vantage point of a quartercentury. First, we provide a historical backdrop by reviewing the activities of the University of Chicago's Jury Project that led to the publication of The American Jury. Then, for those readers who are not intimately familiar with it, we describe the research design and major findings of the book. After that, we turn to its initial-and mixed-review by legal scholars and social scientists. Next, an attempt is made to trace The American Jury's impact on social science research and its treatment in appellate opinions. We conclude with a call for replication of this significant research study and an overall assessment of the legacy of Kalven and Zeisel's volume.

Valerie P. Hans is associate professor of criminal justice and psychology, University of Delaware. Ph.D. 1978, University of Toronto. Neil Vidmar is professor of social science and law, Duke Law School. Ph.D. 1967, University of Illinois-Urbana.

The authors benefited greatly from a 5 Feb. 1991 telephone conference call interview with Hans Zeisel. Professor Zeisel furnished context, insights, and a personal perspective that enhanced our understanding of the development and impact of The American Jury. We also profited from conversations with Judge Abner Mikva, Felice Levine, Shari Diamond, Howard Erlanger, and Michael Saks. Finally Janet Sinder and Ken Hirsh of Duke Law Library provided vital research assistance for the sections on scholarly citations of The American Jury. 


\section{THE UNIVERSITY OF CHICAGO'S JURY PROJECT}

The genesis of The American Jury dates to 1952, when Dean Edward Levi of the University of Chicago's Law School obtained a grant from the Ford Foundation for behavioral research on the law. ${ }^{1}$ Ultimately $\$ 1.4$ million was given to the project, a very substantial sum by the standards of the day. The initial aims of the Chicago group were ambitious and included investigation of three separate lines of research: commercial arbitration, public attitudes toward the tax system, and the jury system. ${ }^{2}$ The tax project was shelved at an early stage, and although the commercial arbitration project was completed, its output was modest. ${ }^{3}$ Attention, and funds, were increasingly channeled to the project on juries.

The field of sociolegal studies is large and robust today, ${ }^{4}$ so the Chicago Jury Project's uniqueness in the 1950 s is worth emphasizing. The Project was notable on a number of fronts. First, it combined the diverse insights and talents of both lawyers and social scientists. Key participants included Harry Kalven, Jr., a noted legal scholar, who joined forces with Hans Zeisel, a well-known methodologist and public opinion analyst, and Fred Strodtbeck, a sociologist specializing in small group processes. Simon and Lynch credit the jury project with inspiring a new tradition of sociolegal research, noting that "[ $t]$ he division of labor employed on that project became a paradigm for future projects involving lawyers and social scientists that continued for several decades." 5

Second, the Project utilized multiple methods to triangulate on the object of study. These included evaluation of jury trial statistics, court observation of jury trials, posttrial interviews with jurors, experimental jury simulations, and questionnaire responses from judges presiding over

1. Our account of the Chicago Jury Project was derived from several sources, including Dale Broeder, "The University of Chicago Jury Project," 88 Nebraska L Rev. 744 (1959); Glenn W. Ferguson, "Legal Research on Trial," 39 Judicature 78 (1955); Kalven \& Zeisel, The American Jury (at v); Jay Katz, ed., Experimentation with Human Beings 67-109 (New York: Russell Sage Foundation, 1972) ("Katz, Experimentation"); Rita J. Simon \& James P. Lynch, "The Sociology of Law: Where We Have Been and Where We Might Be Going," 23 Law $\mathcal{F}^{\circ}$ Soc'y Rev. 825 (1990); and the 5 Feb. 1991 interview with Hans Zeisel (cited in the authors' note).

2. Broeder, 88 Nebraska L Rev. at 744; Ferguson, 39 Judicature at 79; Simon \& Lynch, 23 Law 8 Soc'y Rev. at 827.

3. Simon \& Lynch, 23 Law \& Soc'y Rev. at 827-28.

4. Marc Galanter, "The Legal Malaise; or, Justice Observed," 19 Law $\mathcal{E}$ Soc'y Rev. 537 (1985); Felice J. Levine, "Goose Bumps and 'The Search for Signs of Intelligent Life' in Sociolegal Studies: After Twenty-Five Years," 24 Law \& Soc'y Rev. 7 (1990).

5. Simon \& Lynch, 23 Law \& Soc'y Rev. at 828. Kalven, Zeisel, and Strodtbeck were just three of a substantial number of scholars working on the Jury Project. Dale Broeder took major responsibility for an observational study of jury trials, Philip Kurland and Bernard Meltzer served as directors of the Project, and Rita Simon conducted an important jury simulation study on insanity defense cases. Thomas Callahan and Philip Ennis were listed as collaborators on The American Jury. 
jury trials. ${ }^{6}$ The judicial questionnaire data formed the core of The American Jury, but the book also drew on material gathered in the other lines of research. Harry Kalven was surely justified when in 1955 he claimed the Project was "perhaps the most comprehensive study of the workings of the American jury ever undertaken."?

One additional approach to studying the jury brought some early notoriety to the Jury Project. In their original blueprint for studying the jury, the researchers observed that: "[s]ince the jury room is not open to direct observation ... it will be necessary to attempt to reconstruct the operations of the jury indirectly." 8 However, Paul Kitch, a University of Chicago Law School graduate and Kansas attorney, contacted the Jury Project's director in 1953 to argue that there were serious problems with these indirect methods. ${ }^{9}$ Kitch aggressively lobbied the Project researchers to examine jury deliberations themselves. He assured them that cooperation of the courts could be obtained to record jury deliberations. Although the researchers were initially skeptical and reluctant, a period of negotiation ensued. ${ }^{10}$ U.S. District Judge Delmas C. Hill in Wichita, Kansas, agreed to permit audio recording of civil jury deliberations in his courtroom. ${ }^{11}$ Multiple safeguards were developed to protect the rights of the individuals involved, including permission of the attorneys, strict controls over access to the taped deliberations, and editing of transcripts to ensure anonymity for the jurors, parties, and cases. The jurors themselves were not to be notified on the ground that it might influence deliberation. Abner Mikva, then a young attorney, was hired to oversee the Wichita operation. ${ }^{12}$ Six deliberations were taped in 1954 without incident or publicity. ${ }^{13}$

The following year Judge Hill gave a talk on the project at the Tenth Circuit's Judicial Conference, described the jury taping and played an edited version of one of the recordings. Fred Strodtbeck, identified only as Mr. X, assisted in the presentation. ${ }^{14}$ Three months later, the Los Angeles Times carried a story about the taping. Within days newspapers all over

6. Broeder, 88 Nebraska L Rev. at 747-53.

7. Quoted in Ferguson, 39 Judicature at 79.

8. Katz, Experimentation 70.

9. Kitch derogated the planned Chicago studies as "a so-called research project which basically is dependent upon testing methods which are unscientific to say the least." Katz, Experimentation 71 .

10. Zeisel said that he had reservations about the taping of jury deliberations when it was first proposed, but when a federal judge approved the project, he withdrew his objections (interview, cited in authors' note).

11. Orie L. Phillips, Chief Judge of the Court of Appeals for the Tenth Judicial Circuit, also gave permission. Katz, Experimentation 72-73 (cited in note 1).

12. Mikva went on to become a member of the District of Columbia Circuit Court of Appeals.

13. Ferguson, 39 Judicature at 81 ; Katz, Experimentation 82.

14. Katz, Experimentation 94. 


\section{LAW AND SOCIAL INQUIRY}

the country carried angry reports about the bugging of the jury room. ${ }^{15}$ The Subcommittee on Internal Security of the Senate Committee on the Judiciary convened a special hearing to discuss the jury recordings. It called Dean Levi, Harry Kalven, and others associated with the Jury Project to testify about the incident. Committee members roundly denounced them. ${ }^{16}$ Subsequently, Congress passed a law prohibiting the recording of federal jury deliberations. ${ }^{17}$ Although it is not forbidden in all states, to our knowledge an actual jury deliberation has been taped only once since the Chicago Jury Project's ill-fated effort. ${ }^{18}$

The jury bugging incident was a setback, but the Jury Project members regrouped and continued investigation of the jury along the variety of other fronts contemplated in their original plan. A number of papers and a book on trial delay were completed in the late 1950 s and early $1960 \mathrm{~s}^{19}$ In 1966, 14 years after the first Ford Foundation grant, The American Jury was published. It proved to be the most significant output of the Chicago studies of law and the behavioral sciences.

\section{THE METHODOLOGY AND FINDINGS OF THE AMERICAN JURY}

The centerpiece of The American Jury involved analysis of judicial responses to jury trials. The logic of the research was simple but ingenious. Kalven and Zeisel observed that the judge is "the one serious and significant alternative" (at 9) to the jury. To understand the distinctive contri-

15. Ferguson, 39 Judicature at 81 . Zeisel recounted to us that when the newspapers came out against the jury bugging, they "hadn't a friend in the world." Dean Levi feared for the existence of the Law School (interview, cited in authors' note).

16. The tone toward the researchers was decidedly hostile. Consider Subcommittee Chairman Eastland's exhortation to Dean Levi: "Now, do you not realize that to snoop on a jury, and to record what they say, does violence to every reason for which we have secret deliberations of a jury?" Katz, Experimentation 80.

$\mathrm{McCarthy}$-era red baiting was evident. Subcommittee members implied that radical tendencies might have motivated the jury bugging. Kalven, for example, was asked about his agreement with statements about juries from Vishinsky's Law of the Soviet State (id. at 90), whether or not he read the radical paper Daily Worker (id. at 86), and whether he had written a letter to President Truman requesting clemency for the Rosenbergs who were convicted and executed for spying (id. at 86). Hans Zeisel expressed to us his pride in Kalven's steadfastness at the hearing (interview, cited in authors' note).

17. Act of August 2, 1956, ch. 879, sec. 1, 70 Stat. 935; see 18 U.S.C. $\$ 1508$ (1964).

18. Steven Hertzberg of University of Wisconsin Law School worked with television producers to film a Wisconsin jury deliberation. Permission of all parties including jurors was obtained. Portions of the film were subsequently aired on Frontline, "Inside the Jury Room" (public television program originally aired nationally on 8 April 1986; sponsored by WGBH, Boston, and produced by A. Levin, Media Works, Maplewood, N.J.).

19. A bibliography in The American Jury lists more than 60 articles and the book by Hans Zeisel, Harry Kalven, Jr., \& Bernard Buchholz, Delay in the Court (Boston: Little, Brown, 1959) ("Zeisel, Delay"). Simon's book, The Jury and the Defense of Insanity, was published in 1967 (Boston: Little, Brown) ("Simon, Defense of Insanity"). 
bution that the jury makes to the justice system, it would be ideal to have both judge and jury try the same case and observe the results. Although such a study is impossible in reality, Kalven and Zeisel fashioned a facsimile of it by having the judges presiding over jury trials provide their own verdicts about the appropriate case outcomes. These hypothetical verdicts were then compared to the jury's actual verdicts to determine when trial by judge or by jury would have led to different outcomes.

The exact methodology of the study is well known but bears repeating, especially because this methodology, and the conceptual grounds on which it was based, evoked strong criticism from some scholars and practitioners. A volunteer sample of American trial judges who presided over jury trials responded to a mail questionnaire. For each case, the judge reported the jury's verdict and the verdict he or she would have reached had the judge tried the case alone. The judge's hypothetical verdict was to be made while the jury was deliberating, although there is no way of knowing how many judges complied with this instruction. The judge also provided descriptive information and opinions about the nature of the case, the parties, and the lawyers. The first questionnaire, distributed in 1954-55, was relatively unstructured, while a second questionnaire used in 1958 built on the first to include more specific questions.

The final combined sample that formed the basis of The American Jury included questionnaires from 3,576 criminal jury trials, contributed by 555 judges. ${ }^{20}$ Some judges sent in only a few questionnaires, while others provided a large number. Half of the total number of cases came from the $15 \%$ of judges who provided more than ten cases each.

Kalven and Zeisel analyzed agreements and disagreements between the jury's actual verdict and the judge's hypothetical verdict. The agreement was substantial: In $78 \%$ of the cases, the judge and jury would have reached the same verdict. When judge and jury disagreed, $19 \%$ of the time the juries voted to acquit the defendant when the judge would have convicted and only $3 \%$ of the time did they convict when the judge would have acquitted.21

Kalven and Zeisel attempted to discover the explanations for judgejury disagreement using the converging methods of "reason assessment," that is, the judge's explanation for the cause of disagreement, as well as cross-tabulation of cases on various features. For about $10 \%$ of the cases,

20. Judges also reported on civil trials. There were plans to undertake a companion volume on civil juries; and at least some analysis of the civil jury data was performed (at 63-65; see also Harry Kalven, Jr., "The Dignity of the Civil Jury," 50 U. Va. L. Rev. 1055 (1964)), but the data have never been fully reported. In our interview, Zeisel said that he was "heartbroken" about this failure. Despite a number of efforts, various factors, including a lost codebook when another attempt at data analysis was undertaken many years later, interfered with completion of the civil jury work (interview, cited in authors' note).

21. The figures varied slightly from table to table in the book depending on how the data from hung juries were treated. 
no reason for disagreement could be found. For the remainder, a number of factors, including interpretation of the reasonable doubt standard, sentiments about the defendant, and disagreement with the law seemed to explain the divergence between judge and jury verdicts. These factors appeared to influence jury verdicts largely when the judge reported that the evidence in the case was close and capable of supporting either verdict. Kalven and Zeisel proposed a "liberation hypothesis," which asserted that the closeness of the evidence liberated the jurors to give weight to their own feelings of justice.

Most important, Kalven and Zeisel concluded that judge-jury disagreements were not caused by jury misunderstanding of the evidence. Judges described the evidence in the case as easy or difficult to understand. If jurors disagreed with the judge because they misunderstood the evidence, then disagreement rates should have been higher in the more difficult cases. But disagreement rates were similar in cases with easy and difficult evidence, leading Kalven and Zeisel to declare that factors other than evidence difficulty created judge-jury disagreement.

Much of The American Jury was devoted to analyses of judge-jury disagreements from the questionnaire study. But an additional and significant set of findings described in the book originated from another line of the Jury Project research. Jurors from two urban courts provided their first ballot votes to researchers. Kalven and Zeisel mapped the voting data against the final verdicts reached by these juries and observed that juries beginning with a large majority in either direction usually reached the verdict favored by the majority. Furthermore, hung juries typically began with substantial first-ballot disagreement, suggesting that the ambiguity of the case, rather than the eccentricity of a single hold-out juror, caused juries to hang. Since the final outcome could be predicted from the firstballot vote, Kalven and Zeisel inferred that deliberations were not that important in understanding jury behavior.

Kalven and Zeisel's overall assessment of jury performance was quite positive. They concluded that the jury was generally competent; indeed, in the majority of cases it reached the same verdict as a judge would have reached. Disagreements with the judge and the influence of personal sentiment primarily occurred in ambiguous, close cases in which either verdict would have been appropriate. The jury's war with the law was modest, and hung juries were produced by considerable disagreement among jurors rather than an idiosyncratic hold-out. Kalven and Zeisel's final observation in The American Jury was that "[w] hether or not one comes to admire the jury system as much as we have, it must rank as a daring effort in human arrangement to work out a solution to the tensions between law and equity and anarchy" (at 499). 


\section{BOOK REVIEWS OF THE AMERICAN JURY}

\section{The Scholarly Reaction}

Scholarly reviews of The American Jury were, for the most part, ambivalent to decidedly negative. ${ }^{22}$ Often, some praise was combined with searing criticism. The critics focused on what the Chicago Jury Project had promised and decided that The American Jury had fallen short of expectations. They also pointed to weaknesses in the methodology. In light of the book's continuing prominence among empirical studies of law, a detailed examination of some of the reviews is interesting and educational.

In the University of Pennsyluania Law Review John Kaplan's opening paragraph came right to the point:

The American Jury is only the first major product of the University of Chicago's study of the jury system and as such it may be unfair to consider it in isolation. Later books scheduled for publication in the relatively near future may make clear the case for this mammoth empirical study-a case which regrettably is not made by this book. This, of course, is not to say that the book is a bad one-quite the contrary, it is a very good one. It is just that for scholars of the stature of Professors Kalven and Zeisel-and there are very few of these-and after the amount of advance publicity the study has received, The American Jury comes as somewhat of a disappointment. ${ }^{23}$

Although not trained as a social scientist, Kaplan's major complaint involved the study's methodology. He observed that half of the sample cases had come from just a small number of the judges. More important in his view, however, were the problems of small numbers accruing to multiple disaggregations of the data, and Kalven and Zeisel's tendency to draw conclusions from such small numbers.

As an example he chose Kalven and Zeisel's analysis of the jury's response to statutory rape and their conclusion that juries were influenced by the character of the rape victim. The original number of cases involving statutory rape was 70 . However, Kalven and Zeisel eliminated cases in which the victim was under 13 (and consensual issues were irrelevant),

22. The book was reviewed in 17 American, 1 Canadian, and 3 British law reviews and in major social science journals. Interestingly, in light of the subsequent high frequency of citation among psychologists, it was never reviewed in Contemporary Psychology, a professional periodical reviewing books pertinent to psychology. Reviews also appeared in popular magazines such as the New Yorker, Scientific American, and Saturday Review.

While we have highlighted scholarly reviews offering the harshest criticism of the work, the reader should be aware that the book did receive some generally positive reviews: e.g., D. Phillips, 52 Comell L.Q., 1037 (1967); A. Holtzoff, 53 ABA J. 464 (1967); P. D. McAnany, 11 St. Louis U.L. Rev. 282 (1967).

23. John Kaplan, Book Review, 115 U. Pa. L. Rev. 475 (1967). Footnotes omitted. 
cases in which the evidence was ambiguous, and cases of judge-jury agreement. As a result just 10 cases were available to test the hypothesis that juries were less inclined to convict when the victim had a bad reputation. Kaplan observed that although Kalven and Zeisel acknowledged this weakness in their data (frankly admitting it was "only a weak proof" and "the numbers are desperately small"; at 277-78) they were nevertheless willing to assert that in statutory rape cases the jury differentiated between females with good and bad reputations. Kaplan argued that similar problems of attrition existed with respect to other analyses but deferred further methodological critique on the grounds that the task was more appropriate for scholars in the behavioral sciences, who, he predicted, "will rise at great length to the challenge." 24

Not everything in Kaplan's review was negative. He observed that the book was "the finest work I know for bringing out the many factors which constitute 'jury appeal" "25 and said it should be recommended reading for trial lawyers and law students. Nevertheless, the overall thrust of his review was that the methodology and analyses were incapable of providing definitive support for Kalven and Zeisel's conclusions about the jury.

The book also did not fare well with Abraham Goldstein. Conceding in Law $\mathcal{F}$ Society Review that it was a "significant book," even "a graceful and sophisticated book ... of unquestioned importance," he, too, raised serious methodological issues. ${ }^{26}$ Goldstein centered on Kalven and Zeisel's reliance on "reason assessment," which depended almost completely on the trial judges' evaluation of what the jurors were likely to think.

[W] hen the trial judge says that jurors voted to acquit because they do not like gambling laws ... it is impossible to tell whether the judges are doing any more than attributing to jurors the feelings and sentiments that judges expect jurors to have. As a result, the risk is very great that the entire research design is confined by a stereotype borrowed by the judges from the lawyer-culture. . . . It is difficult to avoid the feeling that the jury may come out in predictable form because trial judges see it that way, not because the jury actually follows the form. ${ }^{27}$

24. Id. at 478 . He could not, however, resist a further methodological observation about weaknesses in the questionnaires regarding the effects of superiority of counsel. He noted that the first version of the questionnaire simply asked the judge to indicate whether the trial lawyers were experienced, whereas the second asked how well the case was tried. While the former question did not assess superiority, both were combined for the data analysis. Furthermore, Kaplan observed that since the instructions did not specify that the lawyer evaluation was to be made prior to the jury verdict, judges may have based their judgments of lawyer superiority on case outcomes.

25. Id. at $478-79$.

26. Abraham S. Goldstein, Book Review, 1 Law $\mathcal{E}$ Soc'y Rev. 148 (1967).

27. Id. at 151 . 
Goldstein also was concerned that "we have no way of knowing whether the judges who say they would decide a case in a particular way would actually have done so." 28

These themes were picked up in other law reviews. The Yale Law Journal carried a lengthy negative review based on a senior studies paper arguing that "[s]erious flaws in methodology gravely weaken the study's major conclusions. As a result, the jury debate remains almost as nonempirical as it was prior to the publication of The American Jury." 29 In an otherwise positive review appearing in the University of Chicago Law Review, Judge Henry J. Friendly commented that "in some instances the sample seems too small to warrant the conclusions drawn from it." 30

In the Northwestem University Law Review, Jon Waltz observed that the title of the book was misleading because it only addressed the criminal jury and noted that "even those who shake off the feeling that they have been promised more than is delivered may feel that the delivery is something less than they had expected from so elaborate and highly publicized a project." 31 He too offered the methodological criticism that the researchers subdivided their sample too far. ${ }^{32}$ Similarly, an evaluation in the Harvard Law Review was not favorable. ${ }^{33}$

As John Kaplan had predicted, social scientists were indeed critical of the methodology. In the American Sociological Review, A. Paul Hare wrote: "What the authors report may well be true, but the work of statistical analysis has been left for someone else." 34 Hare pointed out that of the 155 tables in the book not a single test of significance was provided, even though most of the data were amenable to such tests, and that "a few hours of statistical analysis on a computer would make a significant difference in the credibility of the whole effort." 35 Additionally, he remarked on the facts that the sample of trials was not representative of regions or frequency of crimes, and that a small number of judges provided the bulk of the cases. He also expressed concern about analyses based on extremely small case frequencies. Finally, Hare observed that although the jury is a group and its verdict a product of deliberation processes, the research ignored the jury's small-group characteristics.

\section{Id.}

29. Michael H. Walsh, "The American Jury: A Reassessment," 79 Yale LJ. 142 (1969).

30. Henry J. Friendly, Book Review, 33 U. Chi. L. Rev. 884, 889 (1966).

31. Jon Waltz, Book Review, 62 NW. U.L Rev. 122 (1967). Waltz modified this review for the Joumal of Criminal Law, Criminology, and Police Science (Jon Waltz, Book Review, $58 \mathrm{~J}$. Crim. L. Criminology \& Police Sci. 382 (1967)).

32. Waltz, 62 NW. U.L. Rev. at 122.

33. Harris B. Steinberg, Book Review, 80 Harv. L. Rev. 477 (1966). "If scientific information in the functioning of the jury is desirable and necessary, much of the job of obtaining it remains to be done." Id. at 484 .

34. A. Paul Hare, Book Review, 32 Am. Soc. Rev. 666 (1967).

35. Id. at 667. 
Herbert Jacob raised similar concerns. ${ }^{36} \mathrm{He}$ too noted Kalven and Zeisel's failure to address the social decision-making process and the absence of statistical analysis. The latter problem was

somewhat surprising in the work of as distinguished a practitioner of statistics as Hans Zeisel. It also stands in sharp contrast to the sophisticated discussion of their data collection techniques and problems of bias resulting from the non-response of some judges who were sent questionnaires and the over-response of other jurists. ${ }^{37}$

Jacob expressed hope that "the missed opportunities of this report" would be corrected in subsequent Chicago Jury Project reports.

The reader should not be left with the impression that every review was as negative as those quoted. The evaluation in the American Political Science Review was generally quite positive, though reviewer William Beaney cautioned that the research presented the jury seen only through the eyes of judges. ${ }^{38}$ In the Western Political Quarterly Harry Stumpf stated: "Neither a long list of laudatory adjectives nor a review twice this length would adequately convey the methodological and substantive value" of the research. ${ }^{39}$ He showed prescience in his statement that "[i]f this reviewer rightly interprets the current mood and habits of his social science colleagues, this book will become a familiar tool in the hands of the many political scientists, sociologists, and social psychologists interested in the law." 40 Nevertheless, the important fact is that many reviews, including those in the most prestigious law and social science journals, expressed considerable doubts about the methodology, conclusions, and scholarly contribution of The American Jury.

\section{Explaining Critical Scholarly Reaction}

How does one attempt to explain the reactions of these scholars who reviewed The American Jury? Substantial concern over methodology was an extremely important factor. The sample of judges was unrepresentative; the judge's hypothetical verdict was of uncertain meaning; the method of reason assessment was questionable; the number of cases for some analyses was too small, and statistical tests were not reported.

These are serious problems and should not be treated lightly. However, in fairness to Kalven and Zeisel it must be noted that they addressed

36. Herbert Jacob, Book Réview, 11 Midw. J. Pol. 282, 283 (1967).

37. Id at 283.

38. William Beaney, Book Review, 61 Am. J. Pol. Sci. 770 (1967).

39. Harry P. Stumpf, Book Review, 20 W. Pol. Q. 486 (1967).

40. Id. at 487 . 
all but one in the five chapters devoted to methodology (chs. 3, 4, 7, 37, and 38 ) and in key places in the rest of the book. Indeed, they exhibited so much candor about their data and the shortcomings of them that they facilitated criticism. ${ }^{41}$ Furthermore, when possible they attempted to test for biases by using alternative analyses.

Consider the issue of the nonrepresentative sample of judges. Kalven and Zeisel devoted an entire chapter to the distribution of trials by regions of the country, types of trials, and the judges who reported those trials. Comparing their sample of trials by regions of the United States, they reported that there were marked regional deficiencies. They also contrasted the types of crimes and the number of acquittals represented in their sample with U.S. census figures. After making these comparisons, they concluded that the national statistics were "remarkably like the frequencies in the sample" (at 40), although there were some discrepancies. Finally, Kalven and Zeisel attempted to address the problem of self-selection of judges, but admitted that it was "not an easy one to solve" (at 43). They acknowledged taking only "the next best thing" (at 43) by comparing judge-jury disagreement rates for judges who sent in only a few reports with those who submitted many cases. Although concluding that judicial self-selection had not distorted the sample, Kalven and Zeisel closed their discussion of sample issues with the following qualification:

In the end our conclusions about the sample come down to this: modern social science research on vital problems and living institutions will always be confronted with large practical difficulties; the pure canons of methodology can seldom be followed. In these situations it is important that the researcher into the problems of society be prudent, by being prepared to make some concessions to reality and some compromises with ideal methodology. (At 44) ${ }^{42}$

Kalven and Zeisel discussed the many problems of the mail question-

41. Goldstein, Kaplan, and McAnany were among the reviewers who acknowledged this candor.

42. Two British researchers undertook a statistical critique of sample biases and other problems in The American Jury. A. E. Bottoms \& Monica A. Walker, "The American Jury: A Critique," $67 \mathrm{~J}$. Am. Statistical A. 773 (1972). Bottoms and Walker showed that there was a statistically significant underrepresentation of cases from the South-a fact that Kalven and Zeisel had conceded. Bottoms and Walker also demonstrated that the acquittal rates for certain crimes in Kalven and Zeisel's sample significantly differed from census figures and pointed out possible discrepancies between the 1954 and 1958 data sets.

Kalven and Zeisel offered a brief response. Harry Kalven, Jr., \& Hans Zeisel, "Rejoinder," 67 J. Am. Statistical A. 779 (1972). The rejoinder noted that the book already acknowledged most differences shown by Bottoms and Walker's statistical analyses, and that other data ignored by Bottoms and Walker were consistent with the book's conclusions. The rejoinder reminded readers once again that The American Jury's methodology was an attempt to deal with imperfect data, observing that Bottoms and Walker's critique had a "virginal tone that smacks of experience too limited to textbook methodology." Id. at 779. 
naire with equal frankness. They noted problems of social desirability, candidness of the judge, the hypothetical nature of the judge's verdict, and the lack of assurance that judges followed the instruction to register their verdicts before the jury outcome was known. The extent to which the authors subsequently carried the burdens of proof on these matters is open to debate, ${ }^{43}$ but they cannot be accused of hiding cards under the table.

Goldstein, Walsh, and others took issue with the method of reason assessment. There is merit to this criticism. Kalven and Zeisel argued that judges are uniquely positioned to assess the causes of jury behavior since they preside over many trials that regularly differ along varied dimensions. However, they confessed an inability to know for certain that judges were providing accurate insights into jury behavior rather than stereotypical judicial interpretations. This, of course, was Goldstein's key point. As with sampling matters, Kalven and Zeisel openly acknowledged the limitation even though they chose to put the best face on it. Furthermore, the criticism does not easily apply to some of the cross-tabulation analyses. Consider judge-jury disagreement in difficult or close cases. It seems unlikely to us that judges would anticipate the purposes to which their assessments of evidence difficulty and ambiguity would be put.

Finally, there is the matter of the statistical analyses. There can be little question that in a few instances Kalven and Zeisel pushed their data to the limit. ${ }^{44}$ Nevertheless, they specifically invited the reader to take cognizance of small sample sizes and in every instance presented not only percentages but the raw numbers. Any social scientist and most lawyers could read them and interpret them independently of Kalven and Zeisel.

A remaining methodological question is why Kalven and Zeisel did not report inferential statistical tests, if only simple chi-square analyses. Zeisel's answer to this was that since the sample was not a probability sample, it would have been inappropriate to apply such tests. An extension of this answer appears to lie in Zeisel's philosophical approach to data analysis, which emphasizes the logic of the analysis. A hypothesis is set forth. To test and corroborate the hypothesis, data are disaggregated and crosstabulated and comparisons are made with other data sets. Kalven and Zeisel described it as a process of inference through triangulation..$^{45}$ Even

43. As an example of a debatable assumption, Kalven and Zeisel argued that criticism about the judge's hypothetical verdict was partially nullified by the fact that the verdict is one that judges make routinely, increasing the probability that the simulated verdict would be similar to the real verdict. This does not necessarily follow, particularly if judges, aware that they were participating in a research study, attempted to anticipate the jury's decision.

44. Zeisel acknowledged during our interview that "we were generous to our data" (interview, cited in authors' note). And Kalven and Zeisel confessed in the Joumal of the American Statistical Association that "[t]o be sure, we have taken our chances and have analyzed these unique data to their limits." Kalven \& Zeisel, $67 \mathrm{~J}$. Am. Statistical A. at 779.

45. Id. 
though statistical tests are not incompatible with an inferential logic approach, the tendency to avoid presenting statistical tests is clearly evident in Zeisel's other writings. ${ }^{46}$

In our view, however, the methodological features of the project do not completely explain why The American Jury had such a mixed reception in the book reviews. We believe that some other factors contributed to the negative assessments.

Several reviewers expressed disappointment that so much had been promised by the Chicago Jury Project and viewed the book in light of these expectations. The Ford Foundation's investment of $\$ 1.4$ million in the project was very substantial, and a large number of notable scholars participated. It had the lofty goal of providing an empirical base to law. The American Jury was the first major output of a project that had been in operation for a decade and a half and had received enormous publicity in academic and popular circles. Expectations were so elevated that almost no single scholarly empirical study could have met them.

Another possible factor in the reactions of legal scholars and practitioners was an implicit skepticism of empirical research. In Stumpf's review, he was not sanguine about The American Jury's impact on the legal world: "As for the lawyer and legal scholar, it remains to be seen whether this monumental study, representing the best in socio-legal research and writing, can succeed in penetrating the curtain of Austinian jurisprudence which has for so long isolated most of legal education and research from the methods and findings of modern social science." 47 Indeed, several legal commentators observed that the work only confirmed the obvious. ${ }^{48}$ Paul Meehl, among others, has remarked on the proclivity of lawyers to treat empirical findings-after the fact-as obvious. ${ }^{49}$ To some extent Kalven and Zeisel's generous use of case examples to bolster their empirical results may have added to these proclivities because lawyers could recount their own experiences. A focus on the individual cases could allow them to overlook the systematizing contribution and insights of the book.

Kalven and Zeisel's comparison of judge and jury appears to have been another source of irritation. Throughout the work comparing judgejury disagreements, the authors specifically refused to state whether the judge was right or the jury was right. Yet some scholars argued that the judge-jury comparison invited evaluation of the jury against the "expert"

46. See, e.g., Zeisel, Delay (cited in note 19); Hans Zeisel, "Reflections on Experimental Techniques in the Law, 2 J. Legal Stud. 107 (1973); Hans Zeisel \& T. Callahan, "Split Trials and Time Saving: A Statistical Analysis," 76 Harv. L. Rev. 1606 (1963).

47. Stumpf, 20 W. Pol. Q. at 487.

48. In the Harvard Law Review, for example, Steinberg concluded that the book "only verifies commonly held views." Steinberg, 80 Harv. L. Rev. at 482.

49. Paul E. Meehl, "Law and the Fireside Inductions: Some Reflections of a Clinical Psychologist," in June Louin Tapp \& Felice J. Levine, Law, Justice, and the Individual in Society: Psychological and Legal Issues (New York: Holt, 1977). 
standard of the judge, regardless of the researchers' intent. ${ }^{50}$

As for the reviewers' complaint that the jury deliberation process was largely ignored, Kalven and Zeisel had concluded that deliberation was usually unimportant since the final verdict could be predicted from the first-ballot vote. However, two decades of sociological and psychological research on small-group dynamics had focused on group behavior. Interaction process analysis was the vogue of the day. Lawyers' folklore and popular opinion also placed significance on jury deliberation. By ignoring the deliberative process, Kalven and Zeisel contradicted prevailing wisdom among lawyers and social scientists and were bound to evoke negative reactions. ${ }^{51}$

\section{IMPACT ON JURY STUDIES}

\section{Social Science Research and the Jury}

Initial reaction to The American Jury in book reviews might have suggested to scholars of the time that the book was dead in the water: A project that had a great deal of promise and that was executed by topnotch scholars seemed nevertheless to be so deeply flawed that it could not contribute meaningfully to the research literature or to policy decisions about trial by jury. But The American Jury has defied its critics. Despite early dismissals, the book has become regularly cited as the classic study on jury decision making. The Social Science Citation Index shows that The American Jury has been cited over 900 times. ${ }^{52}$ Table 1 displays these citation counts, and demonstrates that the book's popularity as a reference source has not dimmed even a quarter-century after its publication. Twothirds of the citations to The American Jury came ten years or more after its first printing; in the last five years it has been cited almost 200 times.

The American Jury's longevity stems partly from increased scholarly and popular interest in the jury as an institution. Kalven and Zeisel pointed out in their opening chapter that the jury system has always gener-

50. Geoff Mungham \& Zenon Bankowski, "The Jury in the Legal System," in Pat Carlen, ed., The Sociology of Law (University of Keele Sociological Review Monograph) (Keele, 1976). Mungham and Bankowski argued that comparing the jury's outcome against other groups is problematic because it assumes that there is a right, competent, or efficient verdict. Yet Kalven and Zeisel maintained that the comparison should not be viewed this way: "Our purpose was not to evaluate but only to find out as carefully as we could how the jury actually performs" (at 498-99).

51. Zeisel made the point about lawyers and social scientists in our interview (cited in authors' note).

52. We reviewed the Social Science Citation Index from 1966 through August of 1990 , the latest information available at the time of preparing this essay. We counted all citations to The American Jury, including a small number of citations with incorrect dates of publication or incorrect first initials for Kalven. Book chapters appearing as citations were also included. 
TABLE 1

Citations to The American Jury from the Social Science Citation Index

\begin{tabular}{|c|c|c|c|}
\hline Years & $\begin{array}{l}\text { Overall } \\
\text { Citations }\end{array}$ & $\begin{array}{c}\text { Law Journal } \\
\text { Citations }\end{array}$ & $\begin{array}{l}\text { Social Science } \\
\text { Citations }\end{array}$ \\
\hline $\begin{array}{l}1966-70 \\
1971-75 \\
1976-80 \\
1981-85 \\
1986-\text { Aug. } 1990\end{array}$ & $\begin{array}{l}107 \\
183 \\
240 \\
205 \\
174\end{array}$ & $\begin{array}{r}91(85 \%) \\
134(73 \%) \\
128(53 \%) \\
93(45 \%) \\
100(58 \%)\end{array}$ & $\begin{array}{r}16(15 \%) \\
49(27 \%) \\
112(47 \%) \\
112(55 \%) \\
74(43 \%)\end{array}$ \\
\hline Totals & 909 & $546(60 \%)$ & $363(40 \%)$ \\
\hline
\end{tabular}

NoTE: Entries are the number and percentage of citations occurring in law journals and social science journals. Data from September through December of 1990 were unavailable at the time of manuscript preparation.

ated heated debate, but the 1970 s and 1980 s proved to be particularly contentious times for the institution of the jury. During those decades the fairness of juries in deciding death penalty cases was called into question. In 1972, Furman v. Georgia overturned all death penalty statutes in the United States, citing grave concerns about the fairness and equity of juries' death sentences. ${ }^{53}$ Witherspoon v. Illinois, decided in 1968, questioned whether death-qualified jurors were "uncommonly willing" to sentence a defendant to execution, stimulating research that compared the attitudes and behaviors of supporters and opponents of capital punishment. ${ }^{54}$ The U.S. Supreme Court took up the issues of the jury's size and decision rule, citing social science studies (including The American Jury) in its opinions. ${ }^{55}$ Who served on the jury also became more controversial. Empowered by feminist and civil rights movements, women and racial minorities criticized the jury as a white male bastion. ${ }^{56}$ The Supreme Court ultimately concluded that jury panels must constitute a representative cross-section of the community. ${ }^{57}$ The political trials of the Vietnam era provoked considerable interest in developing social science techniques for jury selection..$^{58}$

53. Furman v. Georgia, 408 U.S. 238 (1972). See discussion in Valerie P. Hans \& Neil Vidmar, Judging the Jury 219-42. (New York: Plenum, 1986). In particular, statistical analyses revealed strong patterns of racial disparity in death sentences. (1984).

54. Craig Haney, ed., "Special Issue on Death Qualification," 8 Law $\mathcal{E}$ Hum. Behav.

55. Ballew v. Georgia, 435 U.S. 223 (1978) (jury size); Apodaca v. Oregon, 406 U.S. 404 (1972) (jury unanimity); Johnson v. Louisiana, 406 U.S. 356 (1972) (jury unanimity).

56. Jon Van Dyke, Jury Selection Procedures (Cambridge, Mass.: Ballinger, 1977).

57. Taylor v. Louisiana, 419 U.S. 522 (1975). See also discussion in Hans \& Vidmar, Judging the Jury 49-57.

58. Richard Christie, "Probability v. Precedence: The Social Psychology of Jury Selec- 
On the civil side, Chief Justice Warren Burger declared the incompetence of juries to decide complex civil cases ${ }^{59}$ and proclaimed a litigation explosion. ${ }^{60}$ An "insurance crisis" developed, and business and insurance industry forces portrayed civil juries as the central villain. ${ }^{61}$ Thus, substantial attacks on both the criminal and civil jury occurred in the decades following publication of The American Jury.

Developments in the social sciences also augured well for expanded study of the jury. The Law and Society Association had just been born, and although its members were few, they built on early efforts in sociolegal studies to examine discretion and the law in action. ${ }^{62} \mathrm{~A}$ perceived crisis in social psychology and a search for relevance increased the desire among laboratory-trained psychologists to work on real-world topics that had meaning and substance. ${ }^{63}$ Theories of attraction, prejudice, and group process were common subjects of laboratory research in the late $1960 \mathrm{~s}$ and early 1970 s and soon would be examined using the vehicle of the jury.

tion," in Gordon Bermant, Charlan Nemeth, \& Neil Vidmar, eds. Psychology and the Law (Lexington, Mass.: Lexington Books, 1976); J. McConahay, C. Mullin, \& J. Frederick, "The Uses of Social Science in Trials with Political and Racial Overtones: The Trial of Joan Little," 41 Law \& Contemp. Probs. 205 (1977); J. Schulman, P. Shaver, R. Colman, B. Emrick, \& R. Christie, "Recipe for a Jury," Psychology Today, May 1973, at 37.

59. Warren Burger, "Is Our Jury System Working?" 118 Reader's Dig., Feb. 1981, at 126; Peter Sperlich, "The Case for Preserving Trial by Jury in Complex Civil Litigation," 65 Judicature 394 (1982) (discussing Burger's opposition to civil jury).

As an interesting footnote to history, Burger was Assistant Attorney General at the time of the Senate Subcommittee hearings about the Wichita jury bugging incident. Subcommittee Chair Eastland quoted from a news article describing a speech Burger made about the incident during Kalven's testimony at the hearing: "A Justice Department official charged today that the University of Chicago Law School plans to eavesdrop on 500 to a thousand juries during its research project into the American jury system. The planting of the microphone in Wichita, Kans., jury room was only the first step in a study of 'very sweeping proposals." " Kalven replied that the statement was false and asserted that "[t]he Department of Justice has good reason to know what the facts are." J. Katz, Experimentation 87 (cited in note 1). (1986).

60. See Marc Galanter, "The Day After the Litigation Explosion," 46 Md. L Rev. 3

61. Stephen Daniels, "The Question of Jury Competence and the Politics of Civil Justice Reform: Symbols, Rhetoric, and Agenda-Building," 52 Law \& Contemp. Probs. 269 (1989).

62. Howard S. Erlanger, "Jury Research in America: Its Past and Future," 4 Law $\mathscr{E}$ Soc'y Rev. 345 (1970); Felice J. Levine, 24 Law \& Soc'y Rev. (cited in note 4). Although, as we discuss, social psychologists came to dominate the field of jury studies, three projects in the law and society tradition provided empirical tests of conclusions from The American Jury. James P. Levine, "Jury Toughness: The Impact of Conservatism on Criminal Court Verdicts," 29 Crime $\&$ Delinquency 71 (1983); Martha Myers, "Rule Departures and Making Law: Juries and Their Verdicts," 13 Law \& Soc'y Rev. 781 (1979); and Barbara F. Reskin \& Christy A. Visher, "The Impacts of Evidence and Extralegal Factors in Jurors' Decisions," 20 Law E Soc'y Rev. 423 (1986).

63. Kenneth Ring, "Experimental Social Psychology: Some Sober Questions About Some Frivolous Values," 3 J. Experimental Soc. Psychology 113 (1967); William McGuire, "Some Impending Orientations in Social Psychology: Some Thoughts Provoked by Kenneth Ring," 3 J. Experimental Soc. Psychology 124 (1967); M. Brewster Smith, "Is Experimental Social Psychology Advancing?" 8 J. Experimental Soc. Psychology 86 (1972). 
An early and highly visible article by David Landy and Elliot Aronson showed the way. ${ }^{64}$ Landy and Aronson borrowed the jury simulation methodology pioneered by Strodtbeck and Simon in the Chicago Jury Project research, but adapted it for their own purposes. The Chicago Jury Project simulations employed people from the jury rolls, presented them with realistic trial simulations, and asked questions central to legal debates. ${ }^{65}$ In contrast Landy and Aronson tested psychological theories about attraction using a jury simulation paradigm. Their subjects were University of Texas college students, their abbreviated stimuli contained information that would be prohibited in a court of law, and subjects rendered sentences rather than verdicts about guilt. Landy and Aronson discovered that the character of the victim and the defendant influenced the college students' sentencing judgments. ${ }^{66}$ In 1969, they reported their findings in the mainstream psychology publication, the Joumal of Experimental Social Psychology. Their concluding paragraph on the relevance of their jury simulation to actual juries, invoking Kalven and Zeisel, became boilerplate for later jury simulations, so it is worth quoting in full:

While the results of these laboratory experiments may have important implications for actual jury trials, a direct and literal extrapolation would be imprudent. Regardless of how seriously our subjects took their task, the fact remains that college students sitting in a classroom are not identical to actual jurors sitting in judgment at a real trial. At the same time, we are encouraged by the fact that in the absence of extraneous stimuli, our results paralleled some of the findings of Kalven and Zeisal [sic] (1966) in their examination of actual cases. ${ }^{67}$

By the mid-1970s the jury simulation methodology had caught on, creating burgeoning citations for Kalven and Zeisel. ${ }^{68}$ Studies of mock ju-

64. David Landy \& Elliot Aronson, "The Influence of the Character of the Criminal and His Victim on the Decisions of Simulated Jurors," 5 J. Experimental Soc. Psychology 141 (1969).

65. For example, Simon's work on juries in insanity cases compared decision making under different legal definitions of the insanity defense. Simon, Defense of Insanity (cited in note 19).

66. The findings on victim character were not strong; they reached statistical significance only when data from two separate studies (and 377 subjects) were standardized and combined. Landy \& Aronson, 5 J. Experimental Soc. Psychology at 150. The authors were aware of Kalven and Zeisel's finding that defendant character influenced judge-jury disagreements when the evidence was ambiguous rather than clear (cf. their detailed discussion at 146) but did not incorporate the insight into their design. Instead, Landy and Aronson used a case in which guile was crystal clear.

67. Id. at 151-52. Their results could just as easily be read as contradicting Kalven and Zeisel, who concluded that defendant and victim attractiveness influenced judge-jury disagreement primarily in cases with ambiguous evidence. Also problematic is the parallel drawn between sentencing and guilt judgments.

68. Weiten and Diamond documented the "spectacular" increase by counting the number of published and unpublished papers reporting jury simulations from 1964 to 1975 . 


\section{LAW AND SOCIAL INQUIRY}

rors (usually undergraduate psychology majors) boomed. Jury simulation proved to be a fertile method for examining attributions of responsibility, theories of attraction, and group decision processes. Yet the use of jury simulation to test psychological theories-and the reliance on Kalven and Zeisel to show the applied relevance of the experimental research-was increasingly criticized on methodological grounds. As early as 1970 , Howard Erlanger wrote that future jury simulations should attempt to approximate real juries. ${ }^{69}$ After drawing attention to weaknesses in mock jury studies, Weiten and Diamond observed in 1979: "Many jury simulation researchers are fond of suggesting that their findings parallel those of Kalven and Zeisel ... [but] the specific nature of the correspondence is not given and consists of the rather general conclusion that defendant attributes may influence juror judgments." 70 In another 1979 essay critical of the jury simulation field, Vidmar noted that while most researchers made reference to The American Jury, he had doubts about whether some of them had read the classic work. ${ }^{11}$ If they had, their reading seemed to be selective. Some of the claims about correspondence between Kalven and Zeisel's research and the findings of jury simulations were unwarranted. And although some jury simulation studies produced results that appeared contradictory to the conclusions of Kalven and Zeisel, no article acknowledged this fact.

Critiques of experimental jury research had impact, resulting in increased attention to its verisimilitude. During the late 1970s and 1980s jury simulation methodology moved closer to the more highly developed simulations of Strodtbeck and Simon. Although unrealistic jury simulations did not disappear, many psychologist researchers developed greater familiarity with law and the institution of the jury, and their research reflected this increased sophistication. ${ }^{22}$ The second wave of research stud-

From 1964 to 1966 , there were 7 studies; 1967-69, 14 studies; 1970-72, 25 studies; and 1973-75, 62 studies. Wayne Weiten \& Shari S. Diamond, "A Critical Review of the Jury Simulation Paradigm: The Case of Defendant Characteristics," 3 Law $\&$ Hum. Behav. 71, 72-73 (1979).

Our own citation count also showed a dramatic increase in social science references to The American Jury. We divided the citations into those from law journals and those from social science journals. Journals devoted to social scientific study of law, such as Law and Hum. Behavior and Law $\mathscr{E}$ Society Review, were categorized as social science journals. Table 1 shows that social science journal citations moved from a low of $15 \%$ of all citations in 1966-70 to a high of $55 \%$ in 1981-85.

69. Erlanger, 4 Law \& Soc'y Rev. at 357.

70. Weiten \& Diamond, 3 Law $\&$ Hum. Behav. at 80.

71. Neil Vidmar, "The Other Issues in Jury Simulation Research: A Commentary with Particular Reference to Defendant Character Studies," 3 Law \& Hum. Behav. 95, 99 (1979).

72. One study, for example, presented a lengthy videotaped trial stimulus to subjects from juror rolls, varying the legally relevant factor of jury decision rule. Reid Hastie, Steven D. Penrod, \& Nancy Pennington, Inside the Jury (Cambridge, Mass.: Harvard, 1983) ("Hastie et al., Inside the Jury"). Other jury researchers began to explore legally important varables such as the jury's size and the impact of death-qualification in jury selection. By 1982 Diamond concluded that the improvements in jury simulation methodology were evidence 
ies, however, shared at least one tendency of the early jury simulation research-they contained citations to The American Jury. ${ }^{73}$

The American Jury undoubtedly affected the substantive topics of jury research, but this influence has operated in conjunction with trends in social science research and is difficult to trace. In the 1970s studies of judgments of responsibility, justice, and defendant character fit well with both Kalven and Zeisel's work and prevailing psychological theories. In the 1980 s research on the processing capabilities of juries combined some original insights from Kalven and Zeisel with the cognitive science emphasis in social psychology. ${ }^{74}$

We suspect that The American Jury's focus on criminal juries_and the failure to publish the companion volume on civil juries-narrowed the attention of jury researchers to the criminal trial setting. Only in the last few years has a significant amount of research on the civil jury taken place, stimulated partly by increased public attention to issues of tort reform and the jury's competence to decide complex cases. ${ }^{75}$

\section{The Book Literature}

Another set of insights about the impact of Kalven and Zeisel's findings comes from the book literature on juries. For this article we examined 12 books about the jury that were published since $1966 .{ }^{76}$ Two books

that the field of psychology and law was maturing. Shari S. Diamond, "Growth and Maturation in Psychology and Law," 17 Law \& Soc'y Rev. 11 (1982).

Interestingly, however, a review of articles bearing on juries published in Law and Human Behavior from 1986 to 1990 showed that one of the most frequent references to The American Jury pertained to the finding that jury verdicts can be predicted by the distribution of the individual members' predeliberation verdicts. Typically, this finding was cited to justify using individuals rather than groups in mock juror studies.

73. Table 1 shows that in the most recent period of citations, social science journals accounted for $43 \%$ of all citations to the work. This probably understates the impact of The American Jury on contemporary social science research, because law reviews have increasingly published both original research and reviews of research.

74. See Nancy Pennington \& Reid Hastie, "Practical Implications of Psychological Research on Juror and Jury Decision Making," 16 Personality and Soc. Psychology Bull. 90 (1990).

75. See Neil Vidmar, ed., 52 Law $\&$ Conteop. Probs., Whole Issue \#4 (1989).

76. Our selection included books containing substantive treatment of the institution of the jury and jury research. We excluded edited books and "how-to" books by jury consultants. The collection of books on the jury is not exhaustive, nor was it meant to be. Rather, we attempted to analyze a reasonable selection of the jury book literature to determine how The American Jury was presented. The books included John Baldwin \& Michael McConville, Jury Trials (Oxford: Clarendon Press, 1979) ("Baldwin \& McConville, Jury Trials"); Paula DiPerna, Juries on Trial: Faces of American Justice (New York: Dembner Books, 1984) ("DiPerna, Juries"); Hubert S. Feild \& Leigh B. Bienen, Jurors and Rape (Lexington, Mass: Lexington Books, 1980) ("Feild \& Bienen, Jurors and Rape"); John Guinther, The Jury in America (New York: Facts on File Publications, 1988 ("Guinther, Jury"); Hans \& Vidmar, Judging the Jury (cited in note 53); Hastie et al., Inside the Jury (cited in note 72); Saul M. Kassin \& Lawrence S. Wrightsman, The American Jury on Trial: Psychological Perspectives (New York: Hemisphere, 1988) ("Kassin \& Wrightsman, American Jury"); Law Reform 


\section{LAW AND SOCIAL INQUIRY}

were published in the 1970 s, while the remaining 10 were published in the 1980 s, providing further evidence of the jury's increased prominence as a subject of study in both popular and academic circles. How frequently did authors refer to The American Jury? What findings were most often described? Were the citations generally accurate?

Most of the books cited The American Jury on roughly 10 pages or so, with general books on the institution of the jury ${ }^{77}$ citing The American Jury more frequently than books with a narrower focus or that reported new research..$^{78}$ Most described the basic methodology of the study but differed in the amount of detail. ${ }^{79}$

Among all the book authors Baldwin and $\mathrm{McC}$ Conville stand out as scathing in their criticism. As background for their own study of the English jury that was patterned on the Chicago Jury Project, Baldwin and McConville discussed The American Jury's failings at some length. ${ }^{80}$ They described the judge-jury agreement study as having "a curiously ham-fisted methodology,"81 pointing out problems in the unrepresentative sample,

Commission of Canada, The Jury in Criminal Trials (Ottawa: Minister of Supply and Services Canada, 1980) ("Law Reform Commission"); Michael J. Saks, Jury Verdicts: The Role of Group Size and Social Decision Rule (Lexington, Mass.: Lexington Books, 1977) ("Saks, Jury Verdicts"); Molly Selvin \& Larry Picus, The Debate over Jury Performance: Observations from a Recent Asbestos Case (Santa Monica, Cal: RAND Corporation, 1987) ("Selvin \& Picus, Debate"); Rita J. Simon, The Jury: Its Role in American Society (Lexington, Mass.: Lexington Books, 1980) ("Simon, The Jury"); and Seymour Wishman, Anatomy of a Jury: The System on Trial (New York: Times Books, 1986) ("Wishman, Anatomy").

77. The books with the most frequent coverage included Hans \& Vidmar, Judging the Jury; DiPerna, Juries; Kassin \& Wrightsman, American Jury; Simon, The Jury; and Wishman, Anatomy.

78. Hastie et al., Inside the Jury, and Saks, Jury Verdicts, primarily cited The American Jury for findings that were directly relevant to their studies of jury size and decision rule. Many of the citations in Hastie et al. related to hung jury rates in unanimous and majority decision rule groups. Both Saks and Hastie et al. mentioned the relationship between firstballot votes and final jury verdicts, especially as it pertained to individuals deadlocking the jury.

Guinther, Jury, whose book reported questionnaire data about the civil jury, cited the broader findings of The American Jury.

Selvin \& Picus's Debate analyzed an asbestos jury's decision making and cired The American Jury only a handful of times, observing that its method of judge-jury agreement was of limited value in evaluating the jury's performance in a specific trial such as the asbestos case under consideration.

Feild and Bienen's Jurors and Rape cited The American Jury primarily for findings related to rape cases, although they also cited it as a source showing the impact of criminal record (at 96) and lawyer prestige (at 97) on juror judgments. They noted that although Kalven and Zeisel are usually cited for the proposition that juries won't convict in rape cases where judges would, the study was dated and judges were probably not free of bias in rape cases (at 204-5).

79. Most accounts of the methodology were not extensive. Hans \& Vidmar, Judging the Jury at 116; Kassin \& Wrightsman, American Jury 16; and Simon, The Jury at 49 had the most elaborate descriptions of the Jury Project's methods. Guinther, Jury xviii, spent a considerable time noting the limitations of the method and sample, as did Baldwin \& McConville, Jury Trials, at $6-8$.

80. Baldwin \& McConville, Jury Trials 6-8; 12.

81. Id. at 6. 
the limited questionnaire, and the bias that Kalven and Zeisel revealed toward trial by jury. In a paragraph reminiscent of the book reviews, they concluded:

it would appear that, after all, Kalven and Zeisel regarded their study as little more than a pilot exercise, employing methods that were far from systematic or rigorous. Though they do not say so in their book, it seems that their book was intended merely to point the way to further research. Measured according to this limited objective, there can be no real doubt about the value of their work, though one might be well advised to be suspicious of the judgment of certain legal commentators whose almost unbridled praise of the book when it first appeared now seems to have been largely misplaced..$^{82}$

Although Guinther noted limits to The American Jury's methodology, as did Selvin and Picus, the tone of Baldwin and McConville's evaluation is in marked contrast to the remainder of the books about the jury.

What data were cited most often? The overall levels of judge-jury agreement were frequently mentioned, as was the tendency in criminal case disagreements for juries to favor the defendant. Another common point was that judge-jury agreement levels were the same in easy and difficult cases. Kalven and Zeisel's conclusion from this relationship, that juries generally understood the evidence, was regularly cited as well..$^{83}$ The jury's tendency to follow the equities and in close cases decide verdicts in line with their sympathies was also discussed, but it was pointed out that deviations from the letter of the law were modest. ${ }^{84}$ Indeed, although Kalven and Zeisel concluded The American Jury with the observation that both friends and critics of the jury would "find new ammunition for their case" (at 499) from the inventory they provided of jury behavior, most book authors used Kalven and Zeisel as favorable evidence of the competence and fairness of the jury.

Findings about the first ballot-final verdict relationship were often

82. Id. at 8. Our reading of the book review literature is obviously quite different. Moreover, the irony of Baldwin and McConville's negative treatment of The American Jury is that their own study was modeled after Kalven and Zeisel's research, but had far more serious methodological problems. See R. Hastie, "Judgment Non Obstantibus Datis," 79 Mich. L. Rev. 728 (1981).

83. Hans \& Vidmar, Judging the Jury 117-18; Wishman, Anatomy 226; DiPerna, Juries 57; Kassin \& Wrightsman, American Jury 121. But Baldwin \& McConville, Jury Trials 12 (footnote omitted), maintained that "to say that judges agree with the verdicts of juries in three-quarters of all cases does not mean that the juries in question must have reached the right verdict in these cases or even that (as Kalven and Zeisel infer from their data) the jury must have understood and followed the evidence. Perhaps the judge and jury reached their decisions in completely different ways, agreeing only in the result."

84. E.g., Hans \& Vidmar, Judging the Jury; Law Reform Commission. 


\section{LAW AND SOCLAL INQUIRY}

cited in the book literature. ${ }^{85}$ Although based on small numbers, the conclusion gained credence over time because it was confirmed by small-group research on the relative impact of majority and minority factions. ${ }^{86}$

It was a pleasant discovery that virtually all of the citations in the book literature to The American Jury were accurate. Two different topics created divergence in citations, but the divergence was understandable given their treatment in the original text. One was the overall level of judge-juror agreement in criminal cases, which Kalven and Zeisel report as $75.4 \%$ excluding hung juries (at 56, table 11 ) and $78 \%$ after redistributing hung juries (at 58, table 12). The book authors' overall levels of agreement ranged from $70 \%$ to $80 \%$, with $78 \%$ being the most frequent. ${ }^{87}$

A second point on which there was some divergence among book authors was the finding that when judge and jury disagreed, the jury was more likely to favor acquittal with a net leniency of $16 \%$. Kalven and Zeisel were quick to point out that "this figure must not be made the basis for a general probability calculus by any defendant, because the cases [showing juror leniency] have been selected for jury trial because they are expected to evoke pro-defendant sentiments" (at 59, footnote omitted). This was the sole finding to create diametrically opposed conclusions by the book authors. Kassin and Wrightsman wrote: "Folk wisdom suggests that judges, as veterans of the courtroom, are tougher on the criminal defendant than naive jurors. Kalven and Zeisel's classic study corroborates this hypothesis." 88 But DiPerna maintained: "One feels instinctively that juries are less tough than judges. However, [Kalven and Zeisel] demonstrated that that conventional wisdom did not hold." She quoted The American Jury's conclusion that the jury "is not fundamentally defendantprone, rather it is non-rule minded; it will move where the equities are." 89

In sum, The American Jury was a potent force in shaping book-length accounts of the jury. All books on the jury cited the volume, often using it

85. Hastie et al., Inside the Jury 27; Hans \& Vidmar, Judging the Jury 110-11; Saks, Jury Verdicts 3.

86. G. Stasser, Norbert L. Kerr \& Robert M. Bray, "The Social Psychology of Jury Deliberations: Structure, Process, and Product," in Robert M. Bray \& Norbert L. Kerr, eds., Psychology of the Courtroom (New York: Academic Press, 1982).

87. DiPerna, Juries: "in about 70 percent of the cases" (at 57); Hans \& Vidmar, Judging the Jury: 78\% (at 117); and "in four cases out of five" (at 245); Guinther, Jury: "better than 75\%" (at xix); Kassin \& Wrightsman, American Jury: "78 percent of the time" (at 16); Simon, The Jury: "80 percent of the time" (at 50); Wishman, Anatomy: "in 75 percent of the cases" (at 226); Selvin \& Picus, Debate: "Kalven and Zeisel concluded that there is little disagreement between judges and juries presented with the same cases." (at 61); Law Reform Commission: "in 25 per cent of the cases the jury gave a different verdict than the judge would have given" (at 9).

88. American Jury 30. See also id. at $16 \& 156$, and Simon, The Jury 50-51, for similar statements.

89. Juries 31. See also Selvin \& Picus, Debate 61-62 for the same quote; and Hans \& Vidmar, Judging the Jury 118 for discussion of how case selection might influence jury leniency. 
as a "natural starting point" 90 to discuss the empirical literature on juries. They reported the major findings of the judge-jury agreement study in a generally positive way. The American Jury's message was that the jury is a competent factfinder, and most authors went along with that conclusion. Authors who were most critical of The American Jury's methodology, such as Baldwin and McConville, Guinther, and Selvin and Picus, still summarized the major findings. ${ }^{91}$ The biting criticism that characterized The American Jury's book reviews was much less evident in the book literature on juries.

\section{LEGAL CITATIONS}

We also examined appellate court citations of The American Jury through a search of the Lexis data base through 1990. The U.S. Supreme Court cited the book in 21 cases and federal appeals courts cited it in 38 cases. State appellate courts cited The American Jury in 79 opinions. In the Supreme Court almost $50 \%$ of the citations were in dissents, whereas in federal and state appeals courts about $96 \%$ of the time the citations were in the majority or concurring opinions. Criminal cases accounted for $98 \%$ of the citations, an understandable percentage given the book's focus on criminal juries. Most Supreme Court citations appeared in death penalty cases.

The content referenced in the citations varied. Cases involving death penalty issues made reference to the chapter on the death penalty and the conclusion that juries exercised discretion in death penalty cases. ${ }^{92}$ The jury size and decision rule cases constituted another set. ${ }^{93}$ Another frequently cited finding involved the influence of extralegal factors such as pretrial prejudice, racial prejudice, prior criminal record, or failure of defendants to testify on their own behalf and the ineffectiveness of judicial instructions as a means of controlling their influence. ${ }^{94}$ One group of cita-

90. Baldwin \& McConville, Jury Trials at 6.

91. Thus Selvin and Picus, Debate, noted that Kalven and Zeisel's judges concluded that juries understood the case (at 45) and that the amount of judge-jury agreement was substantial (at 61). And Guinther, Jury, reported that judge-jury disagreement is similar in easy and difficult cases (at 208), that jurors "heavily weighed-and almost always understood-the evidence presented to them" (at 88 ), and that judges generally approved of jury verdicts (at $82 \& 100$ ).

92. E.g., McCleskey v. Kemp, 481 U.S. 279 (1987); Lockhart v. McCree, 476 U.S. 162 (1986); Spaziano v. Florida, 468 U.S. 447 (1984); Woodson v. North Carolina, 428 U.S. 280 (1976); Furman v. Georgia, 408 U.S. 238 (1972); McGautha v. California, 402 U.S. 183 (1971); Witherspoon v. Illinois, 391 U.S. 510 (1968); United States v. Jackson, 390 U.S. 570 (1968).

93. E.g., Ballew v. Georgia, 435 U.S. 223 (1978); Johnson v. Louisiana, 406 U.S. 356 (1972); Apodaca v. Oregon, 406 U.S. 404 (1972); Williams v. Florida, 399 U.S. 78 (1970).

94. E.g., Marshall v. Lonberger, 459 U.S. 422 (1983) (prior criminal record and judicial instructions); Ross v. Massachusetts, 414 U.S. 1080 (1973) (racial prejudice); Spencer v. 


\section{LAW AND SOCIAL INQUIRY}

tions involved the issue of jury nullification, ${ }^{95}$ and another was concerned with hung juries. ${ }^{96}$ Findings about the jury's responses to rape and the insanity defense were also cited. ${ }^{97}$ Kalven and Zeisel's conclusions regarding jury competence and jury equity propensities were referenced in a number of cases. ${ }^{98}$ Finally, some citations to The American Jury were as a general reference source. We uncovered few instances where the court's citation of a finding or conclusion from The American Jury was clearly erroneous. ${ }^{99}$

In most instances the references were in the footnotes rather than the text of the opinion. Some scholars argue that courts may cite social science literature only to support an opinion formed on other grounds. ${ }^{100}$

Texas, 385 U.S. 554 (1967); United States v. Daniels, 770 F.2d 1111 (D.C. Cir. 1985) (prior convictions); United States v. Peters, 754 F.2d 753 (7th Cir. 1985) (pretrial publicity); United States v. James, 555 F.2d 992 (D.C. Cir. 1977) (prior criminal record); United States v. Cook, 538 F.2d 1000 (3rd Cir. 1976) (prior criminal record); United States v. Fields, 500 F.2d 69 (6th Cir. 1974) (pretrial publicity and instructions); United States v. Henson, 486 F.2d 1292 (D.C. Cir. 1973) (failure to testify in own behalf); United States v. Haynes, 350 F.Supp. 990 (S.D. New York 1972) (racial prejudice); Parish v. State, 477 P.2d 1005 (Alaska S. Ct. 1970) (prior criminal record).

95. E.g., Standefer v. United States, 447 U.S. 10 (1980); United States v. Krzyske, 857 F.2d 1089 (6th Cir. 1988); United States v. Dougherty, 473 F.2d 1113 (D.C. Cir. 1972); United States v. Simpson, 460 F.2d 515 (9th Cir. 1972); People v. Dillon, 34 Cal. 3d 441 (1983).

96. See, e.g., Johnson v. Louisiana, 406 U.S. 356 (1972); United States v. Stratton 779 F.2d 820 (2nd Cir. 1985); United States ex rel. Webb v. Philadelphia Country, 516 F.2d 1034 (3d Cir. 1975); United States v. See, 505 F.2d 845 (9th Cir. 1974); United States v. Miller, 411 F.2d 825 (2nd Cir. 1969).

97. See, e.g., United States v. Wiley, 492 F.2d 547 (D.C. Cir. 1973) (rape); United States v. Cockerham, 476 F.2d 542 (D.C. Cir. 1973) (insanity); United States v. Brawner, 471 F.2d 969 (D.C. Cir., 1972) (insanity); United States v. Gorman, 393 F.2d 209 (7th Cir. 1968) (insanity); State ex rel. Pope v. Superior Court, 113 Ariz. 22; 545 P.2d 946 (1976) (rape); People v. Rincon-Pineda, 14 Cal. 3d 864 (1975) (rape); People v. Smith, 33 Cal. App. 3d 51 (1973) (insanity).

98. See, e.g., Steele v. Taylor, 684 F.2d 1193 (6th Cir. 1982); Wyatt v. United States, 591 F.2d 260 (4th Cir. 1979); United States v. Sheppard, 596 F.2d 114 (D.C. Cir. 1977); United States v. Porter, 441 F.2d 1204 (8th Cir. 1971); Keeten v. Garrison, 578 F. Supp. 1164 (U.S. Dist. Ct. Western N.C. 1984); United States v. Quatermain, 467 F. Supp. 782 (U.S. Dist. Ct. Eastern Penn. 1979); Hovey v. Superior Court, 28 Cal. 3d 1 (1980).

99. The most serious misinterpretation occurred in Williams v. Florida, 399 U.S. 78 (1970). In that jury size case, the Supreme Court cited The American Jury to argue that jurors in the minority on the first ballot are likely to be influenced by the proportional rather than the absolute size of the majority faction. Yer in one of the cited passages, Kalven and Zeisel wrote about the importance of a minority member on the jury having at least one initial ally. Therefore the absolute sizes of minority and majority factions are critical. A jury split 10-2 is not the functional equivalent of a jury split 5-1, contrary to the Court's assertion. See Michael J. Saks, "Ignorance of Science is No Excuse," 10 Trial 18 (1974).

In a few other instances, the implications the court drew from the findings were questionable. Consider the Court's pronouncement in Spencer v. Texas: "[T] he most recent scholarly study of jury behavior does not sustain the premise that juries are especially prone to prejudice when prior-crime evidence is admitted as to credibility. ... The study contrasts the effect of such evidence on judges and juries and concludes that 'Neither the one nor the other can be said to be distinctively gullible or skeptical.' " 385 U.S. 554, 565 n.8 (1967). Page citation omitted.

100. See generally David L. Faigman, “ 'Normative Constitutional Fact-Finding': Ex- 
Indeed, even in Ballew v. Georgia, which contained the most extensive discussion of findings from The American Jury, this admonition applies. ${ }^{101}$ Nevertheless, it seems clear that to the extent that courts need to make reference to how juries behave they turn to Kalven and Zeisel's work and with positive appellations. Reminding us of the book literature are such judicial quotes as "the most ambitious empirical study of jury behavior that has ever been attempted,"102 and "[t]hese observations of history and philosophy are underscored and illuminated, in terms of the current place of the jury in the American system of justice by the empirical information and critical insights and analyses blended so felicitously in $\mathrm{H}$. Kalven and H. Zeisel, The American Jury." 103

\section{THE AMERICAN JURY SHOULD BE REPLICATED}

As our review of the social science literature makes clear, The American Jury began the modern field of jury studies and is still a significant force within it. Perhaps part of the explanation for why it continues to be cited so frequently is that no subsequent project has possessed the Chicago Jury Project's comprehensiveness, breadth, and scope. ${ }^{104}$

Replication of the Kalven and Zeisel research is much overdue. While The American Jury was published a quarter-century ago, the original data

ploring the Empirical Component of Constitutional Interpretation," 139 U. Pa. L. Rev. 541 (1991); William C. Thompson, "Death Qualification After Wainuright v. Witt and Lockhart v. McCree," 13 Law \& Hum. Behav. 185 (1989); Phoebe C. Ellsworth, "Unpleasant Facts: The Supreme Court's Response to Empirical Research on Capital Punishment," in Kenneth C. Haas \& James A. Inciardi, eds., Challenging Capital Punishment (Newbury Park, Cal.: Sage, 1988); E. D. Tanke \& T. J. Tanke, "Getting Off a Slippery Slope: Social Science in the Judicial Process," 34 Am. Psychologist 1130 (1979); Neil Vidmar, "Assessing the Impact of Statistical Evidence: A Social Science Perspective," in Stephen E. Fienberg, ed., The Evolving Role of Statistical Assessments as Evidence in the Courts 304-10 (New York: Springer Verlag, 1989) ("Fienberg, Statistical Assessments").

101. Ballew v. Georgia, 435 U.S. 223 (1978). See Tanke \& Tanke, 34 Am. Psychologist.

102. Marshall v. Lonberger, 459 U.S. 422 (1983).

103. United States v. Dougherty, 473 F.2d 1113 (D.C. Cir. 1972).

104. Despite an abundant crop of jury simulation studies, studies of actual jury cases remain rare. Although British researchers Baldwin and $\mathrm{McC}$ Conville attempted a partial replication and extension of the Kalven and Zeisel study, they encountered significant difficulties. Study of the verdicts of actual juries appears to be increasing: the Federal Judicial Center, the RAND Corporation, the American Bar Foundation, and individual investigators have all examined jury verdicts in recent work.

It is interesting to speculate about why there have not been more efforts to replicate and extend Kalven and Zeisel's classic study of judge-jury agreement. The time, energy, financial resources, and coordination required for a similar national study of jury decision making would be considerable. The methodological difficulties that confronted Kalven and Zeisel would also challenge other researchers. Furthermore, a large, multi-investigator project involving field research is at odds with the typical research strategies of many jury researchers. Often trained as social psychologists, they tend to prefer laboratory simulation research and work as single investigators. Finally there is the limited cachet of replicating a well-known study. 
were collected in the 1950 s and are almost 40 years old. Many changes have taken place in the jury system and in society at large that might well limit the generalizability of the findings to the contemporary jury.

Probably the most critical change is that today the jury is much more representative of the community than it was during the $1950 \mathrm{~s}^{105}$ Although the judiciary has also become more democratized, it still represents a much narrower segment of society than the jury. If life experiences of decision makers influence their judgments, juries and judges might disagree more now than they did in the 1950s when Kalven and Zeisel collected their data. ${ }^{106}$

Other changes in the jury system could also affect jury functioning. The Supreme Court upheld the use of six-person civil juries in federal cases $^{107}$ and sanctioned the right of state trial juries to reach nonunanimous decisions. ${ }^{108}$ Empirical research shows that smaller juries and majority verdicts may lessen the representativeness and reliability of jury decisions. ${ }^{109}$ Juries of the 1990s also face more scientific, technical, and expert evidence than they did three or four decades ago. ${ }^{110}$ How do they cope under these changed circumstances?

Societal changes have taken place that might influence the judge-jury agreement rate. ${ }^{111}$ The civil rights and feminist movements may have affected jurors' perceptions of litigants and cases such as those involving racial discrimination and rape. Public concerns about crime could have erased the greater leniency of juries toward criminal defendants in jury trials documented by The American Jury. ${ }^{112}$

Changes in the jury and its sociopolitical environment have been so

105. Hans \& Vidmar, Judging the Jury 47-61 (cited in note 53). The Jury Selection and Service Act of 1968 requires selection of federal jury panels from voters' lists; many states follow the same practice. Court decisions and technical improvements, such as the use of computerized records and multiple source lists, have further increased the representativeness of the jury.

106. In a discussion of jury prejudice, Hans and Vidmar discuss how more representative juries might increase judge-jury disagreement. In a case involving minority members, a jury containing minorities could explain to other jurors the meaning and implications of words and actions by the participants, thus increasing the competence of the jury compared to a white middle-class judge: "The jury would have insights about the meaning of the evidence that were beyond the knowledge of the judge. The judge would, therefore, favor one verdict and the jury another-and the jury would be correct." Hans \& Vidmar, Judging the Jury 142.

107. Colgrove v. Battin, 413 U.S. 149 (1973).

108. Johnson v. Louisiana, 406 U.S. 356 (1972); Apodaca v. Oregon, 406 U.S. 404 (1972).

109. Hans \& Vidmar, Judging the Jury 165-76; Hastie et al., Inside the Jury 35-36 (cited in note 72); Saks, Jury Verdicts 90-91 (cited in note 76); Hans Zeisel, "And Then There Were None: The Diminution of the Federal Jury," 38 U. Chi. L. Rev. 710 (1971).

110. Michael J. Saks \& Richard Van Duizend, 80-84 The Use of Scientific Evidence in Litigation (Washington, D.C.: National Center for State Courts, 1983); Fienberg, Statistical Assessments (cited in note 100 ).

111. Guinther, Jury xviii (cited in note 76).

112. Id. at xix. See also James P. Levine, 29 Crime $\mathcal{E}$ Delinquency 71 (cited in note 62). 
substantial that it is an open question whether Kalven and Zeisel's major findings on the criminal jury-rates of judge-jury agreement, the jury's sense of justice, and first ballot-final verdict relationships-would replicate today. Their important conclusions that juries understand the evidence and wage only a modest and polite war with the law could be timedependent. The twenty-fifth anniversary of the book's publication is a fitting occasion to call for replication and extension of this ground-breaking study.

A study of civil juries should probably be the departure point for any research undertaking. In addition to the societal changes described above, there have been major shifts in the intervening decades in the types of civil cases placed before juries and in the complexities of the issues they must decide. ${ }^{113}$ While The American Jury was concerned with criminal trials and the changes that we have enumerated affect criminal as well as civil trials, the civil jury is the more controversial institution. Critics have charged that civil juries are capricious, prejudiced against minority and female plaintiffs, biased against deep pocket defendants, prone to excessive awards, and incompetent to rationally decide complex trials. ${ }^{114}$ Sound data about contemporary rates of, and reasons for, judge-jury disagreement would go a long way toward providing more rational discussion in a controversy that has been marked by uninformed opinions and politically motivated allegations.

\section{CONCLUSION}

We begin our conclusion with a personal note about our assessment of The American Jury. We were on record as among its admirers before we undertook this essay. ${ }^{115}$ We nevertheless hoped to offer an objective evaluation of the work, examining both its strengths and weaknesses from the perspective of a quarter-century. After several rereadings of the volume, tracing its origins and its early scholarly reception, and documenting its

113. See, e.g., Valerie P. Hans, "The Jury's Response to Business and Corporate Wrongdoing," 52 Law \& Contemp Probs. 177, 178-82 (1989); Mark A. Peterson, Civil Juries in the 1980s: Trends in Jury Trials and Verdicts in California and Cook County, Illinois (Santa Monica, Cal.: The RAND Corporation, 1987).

114. See Daniels, 52 Law $\mathscr{E}$ Contemp. Probs. (cired in note 61), for a review of the charges against the jury. See also Albert Alschuler, "The Shortage of Adjudicative Services and the Need for a Two-Tier System in Civil Cases," 99 Harv. L Rev. 1808 (1986); Stephen Daniels \& Joanne Martin, "Myth and Reality in Punitive Damages," 75 Minn. L Rev. 1 (1990); Marc Galanter, "Jury Shadows: Reflections on the Civil Jury and the "Litigation Explosion," " in The American Civil Jury (Washington, D.C.: Roscoe Pound-American Trial Lawyers Foundation, 1987) at 15-42; Peter Huber, Liability: The Legal Revolution and Its Consequences (New York: Basic Books, 1988); Sperlich, 65 Judicature (cited in note 59).

115. We cited the findings of The American Jury frequently in our book, and described it as "a landmark study." Hans \& Vidmar, Judging the Jury 116. 
continuing vitality as a reference source in scholarly and legal writings, our positive evaluation is undiminished. Indeed, it has increased.

Certainly the study on which The American Jury was based had flaws and limitations, as do all research endeavors. Kalven and Zeisel faced additional challenges because of the ground-breaking nature of their work. ${ }^{116}$ In our view, one of the impressive strengths of the book was that it confronted its limitations head-on and in ways that went far beyond lip service. It considered how features of the sample and design might produce skewed results, and when possible it employed convergent methods to examine alternative hypotheses. With the sole exception of the failure to report inferential statistics we could not find criticisms that Kalven and Zeisel did not attempt to meet on their own. It must also be remembered that from its inception the research that formed the basis of The American Jury was never intended to stand by itself, to be the final word. Rather it was conceived as only one among diverse research approaches to empirical examination of the jury; and it should be judged within that framework.

We have raised the possibility that the data and conclusions of the work are time-bound or inapplicable to today's juries. Yet Kalven and Zeisel themselves anticipated that their research might one day be dated. In the closing section of The American Jury, they said: "We have noted that at this moment in history the jury's quarrel with the law is a slight one. But there have been times when the difference was larger and such times may come again" (at 499). Whether juries perform differently today can be proven or disproven by a contemporary replication, using the original work as a baseline.

We should make another point that will be obvious to any contemporary reader of the volume. Despite Kalven and Zeisel's formal position that evaluation of the jury's performance is a normative matter that lies outside empirical results, their enthusiasm for the institution is evident throughout the book. Some might say that it clouded their objectivity. Yet we reiterate the fact that they presented their data for all to see and to draw their own inferences. Furthermore, whatever their limitations, the data captured something essential about the jury system. The many empirical studies undertaken in the last quarter-century support Kalven and Zeisel's central conclusion: that a jury composed of laypersons can, much

116. As Kalven and Zeisel noted:

We aspired to deal with imperfect data, obtained at great cost and in the teeth of formidable difficulties. ... Ours was a study of a large and unknown territory. Somewhat romantically seen, it was not unlike a first expedition to the bottom of the sea. There is only one way to advance our knowledge and to correct whatever wrong conclusions we may have reached: another expedition that will bring new data from the depths.

Kalven \& Zeisel, at 779 (cited in note 42). 
more often than not, responsibly and competently decide matters of importance to society.

Finally, we want to remark on another aspect of The American Jury that makes it so special: the high quality of the interdisciplinary collaboration. The overriding goal of the Chicago Jury Project was to bring the insights and methodologies of the social sciences to bear on law and legal institutions. In our interview, Professor Zeisel attributed the Jury Project's success to "a lucky combination of two people obsessed with the same goal, namely, Harry Kalven, [whose aim was] to enlarge legal analysis into the factual field, and me, whose ambition was to show that empirical social science research could do something important for the law."117 Although the field of law and society has grown large and vigorous over the past quarter-century, The American Jury stands as an unsurpassed example of what may be achieved if law scholars and social science scholars study a problem together.

Like the jury, the research scholar must weigh conflicting pieces of evidence and then decide who has carried the burden of proof. We conclude that The American Jury merits its reputation as a classic work, and venture the opinion that its influence will continue to be felt at the end of another quarter-century.

117. Zeisel credired Edward Levi with making this observation initially. Clearly it reflected Zeisel's view as well. (interview, cited in authors' note). 
